\title{
A forgotten oat head aspiration in an adult patient
}

Ugur Gonlugur ${ }^{1}$, Ersin Karabacak², Asli Muratli ${ }^{3}$ Arzu Mirici ${ }^{1}$

\author{
1Department of Chest Diseases, Faculty of Medicine, Canakkale Onsekiz Mart \\ University, Turkey \\ 2Department of Biology, Faculty of Science and Arts, Canakkale Onsekiz Mart \\ University, Turkey \\ 32Department of Pathology, Faculty of Medicine, Canakkale Onsekiz Mart University, \\ Turkey
}

Submitted: 30 April 2012

Accepted: 26 July 2012

Arch Med Sci 2014; 10, 5: 1066-1067

DOI: 10.5114 /aoms.2012.30984

Copyright (C) 2014 Termedia \& Banach

Non-resolving or slowly resolving pneumonia in adults represents a diagnostic challenge for chest physicians. We present an interesting case with a forgotten foreign body as a rare cause of slowly resolving pneumonia. A 47-year-old woman was admitted for right-sided chest pain of three months' duration. The patient had chronic cough for years, and was misdiagnosed as suffering from chronic bronchitis and asthma. She did not have a mental disease, neuromuscular disorders or use of sedative and hypnotic drugs. Chest computed tomography scan showed a tumor-like lesion (Figure 1), and a secondary lesion due to pneumonia or atelectasis. A foreign body was removed during diagnostic examination with a fibreoptic bronchoscope under local anesthesia (Figure 2). There was also granulation tissue at the posterior wall of the right lower lobe bronchus (Figure 3). Morphological examination of the foreign body was consistent with oat head. The patient reported that she had been farming oats 20 years ago.

Occult tracheobronchial foreign body aspirations are infrequently seen in adults. It may be undetected for months to years [1], as in our case. In some cases with delayed diagnosis, pneumonitis [1] and granulation tissue appear surrounding the foreign body [2]. The oat head had probably been aspirated 20 years ago in our patient. Clinical and radiological features were consistent with pneumonitis and granulation tissue. The aspiration of a grass inflorescence can cause two different clinical pictures: obstructive type characterized by recurrent pneumonia and bronchiectasis; and migratory type, presenting with pleural or mediastinal complications [3]. An oat head moves unidirectionally, and it is impossible to expectorate once aspirated because of the nature of the structure. Although 5 cases of oat head aspiration have been reported in childhood [4], only 2 case reports $[5,6]$ in the adult population have been presented in the literature.

\author{
Corresponding author: \\ Ugur Gonlugur MD \\ Canakkale Onsekiz Mart \\ Universitesi Tip Fakultesi \\ Gogus Hastaliklari \\ Anabilim Dali \\ 17100, Canakkale, Turkey \\ Phone: +90 2862635950 \\ Fax: +902862183637 \\ E-mail: gonlugur@gmail.com
}



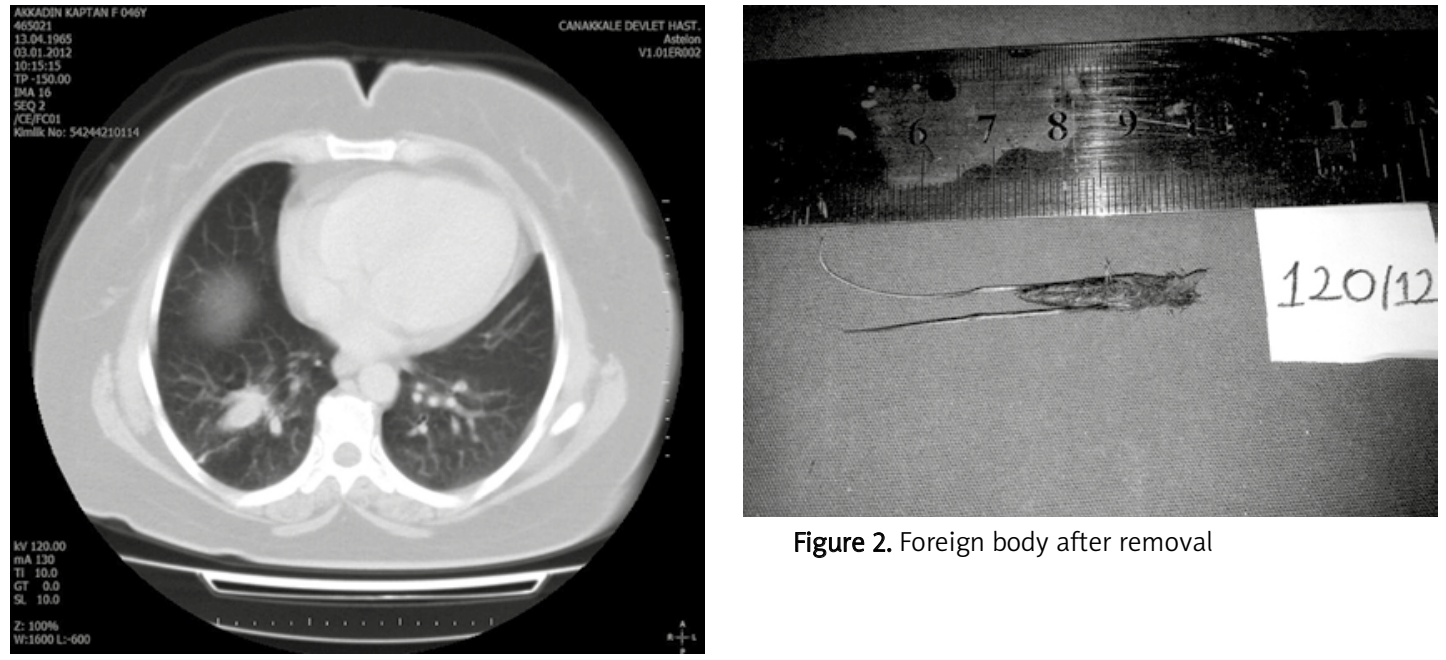

Figure 2. Foreign body after removal

Figure 1. A chest-CT scan showing a smooth ovoid lesion in the right lower lobe

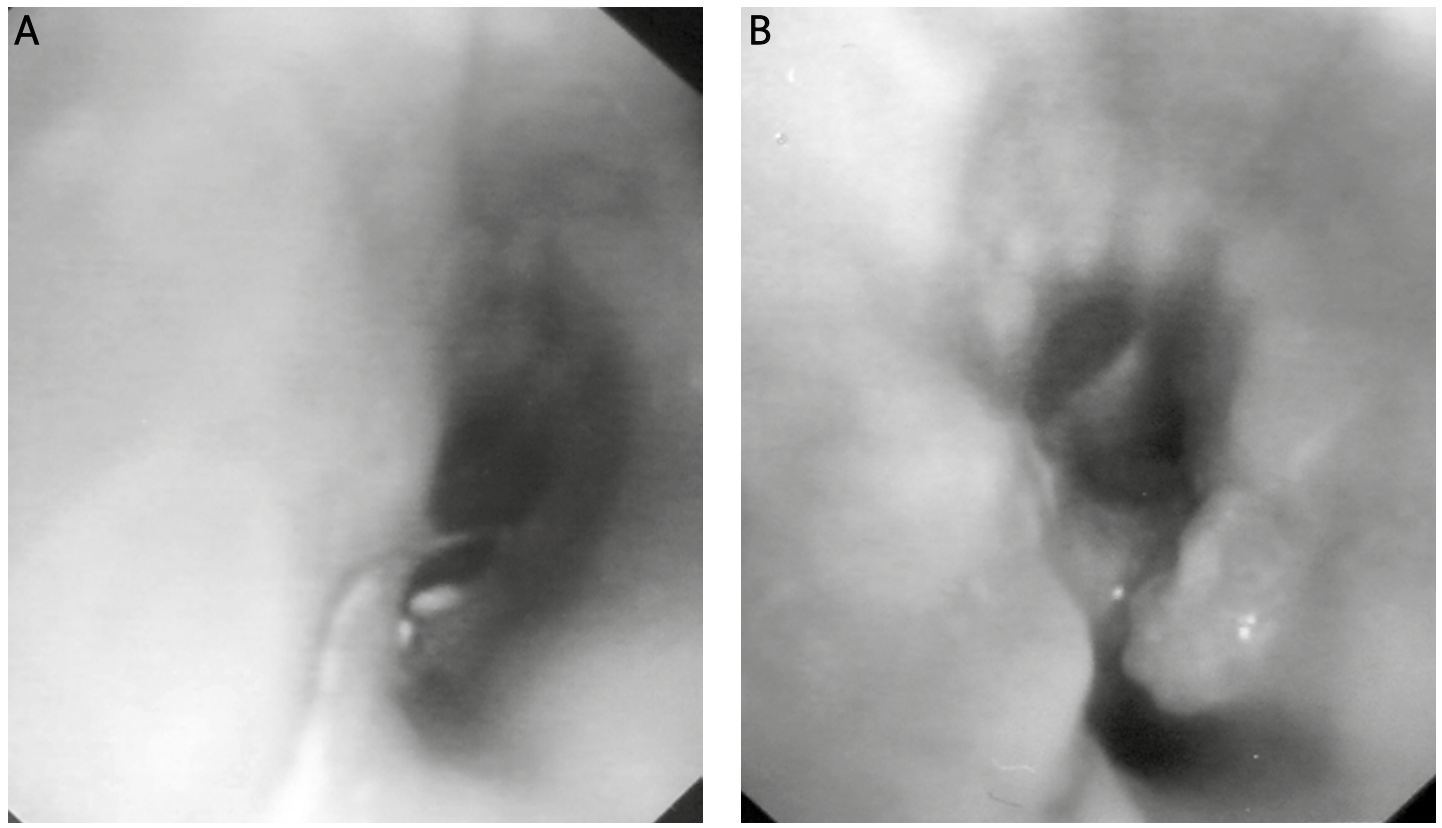

Figure 3. Endoscopic aspect of foreign body and a mass suggestive of granulation tissue on the mucosa

\section{References}

1. Sokouti M, Montazeri V. Delayed massive hemoptysis 20 years after lung stabbing: an unusual presentation. Eur J Cardiothorac Surg 2007; 32: 679-81.

2. Karakoc F, Cakir E, Ersu R, et al. Late diagnosis of foreign body aspiration in children with chronic respiratory symptoms. Int J Pediatr Otorhinolaryngol 2007; 71: 241-6.

3. Cankorkmaz L, Köylüoğlu G, Atalar MH, Güney C, Arslan MS. An interesting journey of a grass inflorescence from broncho to dorsum: case report. Tuberk Toraks 2010; 58: 89-92.

4. Maayan C, Avital A, Elpeleg ON, Springer C, Katz S, Godfrey $\mathrm{S}$. Complications following oat head aspiration. Pediatr Pulmonol 1993; 15: 52-54.

5. Yellin A, Tomer A, Zwas ST, Hassin D, Lieberman Y, Bank H. An unusual case of empyema; intrapleural migration of an inhaled oat head in an adult. Thorac Cardiovasc Surg 1983; 31: 317-9.

6. Dilege S, Toker A, Tanju S, Kalayci G. An unusual intrapleural foreign body: ignored aspiration. Eur I Cardiothorac Surg 2002; 21: 593-4. 